\title{
ADSORPTION AND FLUORESCENCE OF FAT-SOLUBLE FLUORESCENT DYES ON CLASS I AND CLASS III SACCHAROMYCES CEREVISIAE
}

\author{
R. M. LYCETTE AND L. R. HEDRICK \\ Biology Department, Illinois Institute of Technology, Chicago, Illinois
}

Received for publication 26 June 1962

\begin{abstract}
Lycette, R. M. (Illinois Institute of Technology, Chicago) AND L. R. HEDRICK. Adsorption and fluorescence of fat-soluble fluorescent dyes on class I and class III Saccharomyces cerevisiae. J. Bacteriol. 85:1-6. 1963.-Class III cells of the brewery yeast Saccharomyces cerevisiae flocculate, but class I cells do not, when cultured in an organic YM medium. Class III cells adsorb the fat-soluble stilbyl-triazole fluorescent dye (STC) more readily and produce more fluorescence than do class I cells. This suggests that cells of the class III yeasts have more lipids or more phospholipids on their surface than do cells of class I yeasts. Fluorescence of STC in the absence of cells is pH-independent, but adsorption of the compound on the surface of cells, with the associated fluorescence, is $\mathrm{pH}$-dependent. As the $\mathrm{pH}$ level was decreased within the range of $\mathrm{pH} 9$ to 0 , and as the temperature was elevated within the range of 0 to $40 \mathrm{C}$, there was an increase in adsorption and a corresponding increase in fluorescence. Maximal adsorption was attained in less than 15 min when the cells and dye were shaken at $26 \mathrm{C}$. Cells of class III adsorbed $2.5 \mu \mathrm{g}$ of STC per $3.25 \mathrm{mg}$ (dry wt) of cells. The kinetics of adsorption follow the Langmuir monomolecular model.
\end{abstract}

In a previous publication, Lycette and Hedrick (1961) announced the use of the fat-soluble fluorescent stilbyl-triazole compound for indicating that flocculent brewers' yeast cells have more surface lipids than do their nonflocculent counterparts. Darken $(1961,1962)$, with the more polar diaminostilbene compound, studied the differential adsorption of this chemical by a variety of microorganisms and the corresponding fluorescence of the adsorbed dye. Bekken and Tasman (1942) and Mankiewicz (1952) employed the fluorescent dye auramine $\mathrm{O}$ in cytological studies of the mycobacteria. Removal of lipids from such organisms decreased the degree of adsorption and resulting fluorescence of this amino dye on the cells.

The fluorescent dye used in the present work, unlike those reported by other workers, is extremely hydrophobic. It is soluble in fats, waxes, and resins, and is strongly fluorescent in the ultraviolet range. These characteristics enable its use for the detection of lipids in trace quantities. This paper is an amplification of the preliminary report, and includes the method of adsorption and the effect of physical factors upon the rate of adsorption and the degree of fluorescence.

\section{Materials and Methods}

The fat-soluble fluorescent dye is a 2-(stilbyl4')-4,5-arylo-1,2,3-triazole compound (Geigy Chemical Corp., Ardsley, N.Y.) hereafter referred to as STC. This substance has a very low solubility in water and was therefore dissolved in fat-free acetone. In most experiments, $5 \mathrm{mg}$ of STC were dissolved in $100 \mathrm{ml}$ of acetone. This acetone solution was diluted with three parts of distilled water, thus giving an acetone-water mixture, with each $100 \mathrm{ml}$ containing $1.25 \mathrm{mg}$ of STC.

The yeasts used were class I and class III Saccharomyces cerevisiae furnished by R. B. Gilliland of Arthur Guinness and Sons Co., Dublin, Ireland. Class I cells remain in suspension during the entire fermentation period. Class III cells flocculate when the specific gravity of the wort is about 1.024, which is prior to the desired completion of fermentation.

Stock cultures of these strains were grown on YM agar with a composition (per liter of medium) of: yeast extract, $3 \mathrm{~g}$; peptone, $5 \mathrm{~g}$; glucose, 10 $\mathrm{g}$; and agar, $20 \mathrm{~g}$. For YM broth, the agar was omitted. In a few experiments, cells were cultured in the defined salts-vitamin-glucose medium of Wickerham (1946), with 2 g/liter of Sheffield's casein hydrolysate as a nitrogen source. 


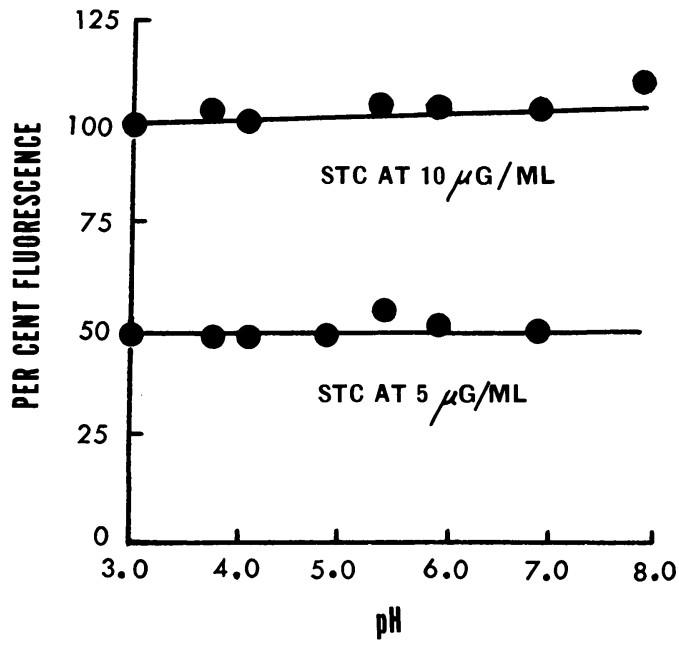

FIG. 1. Effect of $p H$ on fluorescence of the dye STC in the absence of yeast cells.

Cells used for the inoculation of 2-liter conical growth flasks were cultured in $100 \mathrm{ml}$ of $\mathrm{YM}$ broth for $24 \mathrm{hr}$, then centrifuged, and the supernatant liquid was discarded. These cells were added to sterile $0.001 \mathrm{~m}$ phthalate buffer $(\mathrm{pH}$ 3.8 ) in a sterile flask until the optical density (OD) was 1.8 at $610 \mathrm{~m} \mu$ (Coleman spectrophotometer); $10 \mathrm{ml}$ of this suspension were inoculated into 1 liter of YM broth. The flasks were incubated on a rotary shaker for $72 \mathrm{hr}$ at $28 \mathrm{C}$.

The cells cultured for $72 \mathrm{hr}$ were washed three times with phthalate buffer. Washed cells were added to phthalate buffer $(\mathrm{pH} 3.8)$ in a flask to attain an OD of 1.30. Previous experiments had indicated that low $\mathrm{pH}$ values favored fluorescence; therefore, the $0.001 \mathrm{~m}$ phthalate buffer $(\mathrm{pH} 3.8$ ) was used for suspending the cells. If the experiments were done with flocculated class III cells, glucose was added to the buffer as a deflocculating agent, so that the final glucose concentration was $10 \%$. As class I cells were not flocculated, it was not necessary to add glucose to these cells; prior experiments had shown that the addition of $10 \%$ glucose had no effect upon the degree of fluorescence.

From the flask, $9 \mathrm{ml}$ of the cell suspension were added to a series of calibrated $18-\mathrm{mm}$ colorimeter tubes. Then, exactly $1.0 \mathrm{ml}$ of STC, in the acetone-water mixture, was added to $9 \mathrm{ml}$ of the cell suspension. If the acetone-water mixture contained $1.25 \mathrm{mg}$ of STC per $100 \mathrm{ml}$, then each $\mathrm{ml}$ of the cell suspension contained
$1.25 \mu \mathrm{g}$ of the dye. The mixture was shaken for at least $10 \mathrm{~min}$ on a platform shaker at 90 to 100 cycles $/ \mathrm{min}$, in a room at $26 \mathrm{C}$. The yeast cells were centrifuged from the STC mixture and washed three times with buffer ( $\mathrm{pH} 3.8$ ). Fluorescence readings were taken on a Coleman photofluorometer, model $12 \mathrm{~B}$, with no. 12,221 primary and 12,222 secondary filters. The primary filter does not pass light with a wavelength above $365 \mathrm{~m} \mu$, and the secondary filter passes radiation above $400 \mathrm{~m} \mu$. Readings were taken using maximal sensitivity and $5 / 7$ incident light, i.e., the primary filter $2 / 7$ blocked off. The fluorescence standard was $1 \mu \mathrm{g}$ of quinine sulfate per $\mathrm{ml}$ of distilled water which had been adjusted to a $\mathrm{pH}$ of 1.0 with $\mathrm{H}_{2} \mathrm{SO}_{4}$.

For the effect of $\mathrm{pH}$ upon the dye and dyeplus-cells in buffer, stock solutions of $0.1 \mathrm{M}$ buffers in the $\mathrm{pH}$ ranges of 1 to 12 were prepared according to Gortner (1949). When needed, each buffer was diluted 1 to 9 , and then $1 \mathrm{ml}$ of the appropriate buffer was added to a separate 18$\mathrm{mm}$ tube containing $8 \mathrm{ml}$ of yeast cells suspended in $10 \%$ glucose without other added buffers, or to $8 \mathrm{ml}$ of $10 \%$ glucose without cells.

For the fluorescence microscope observations, the ultraviolet (UV) source was $200 \mathrm{w}$ (no. 633, American Optical Co.). The exciter filter was Corning no. 5840 shielded with heat-absorbing glass. A Wratten $2 \mathrm{~B}$ barrier filter was used in the microscope eyepiece.

\section{Results}

Effect of physical conditions on fluorescence. In experiments to determine the effect of $\mathrm{pH}$ levels on the degree of fluorescence of the dye without yeast cells, $1 \mathrm{ml}$ of the proper concentration of STC was added to each buffer, so that the final dye concentration was $5 \mu \mathrm{g} / \mathrm{ml}$ for one series and $10 \mu \mathrm{g} / \mathrm{ml}$ for the other series. Each solution was thoroughly mixed, and, after $15 \mathrm{~min}$ at $26 \mathrm{C}$, the extent of fluorescence was determined. The degree of fluorescence of STC in the absence of cells is independent of $\mathrm{pH}$ levels in the range of 3.0 to 8.0 (Fig. 1).

In studies of the effect of $\mathrm{pH}$ levels on fluorescence of STC when adsorbed on class I and class III cells, the dye concentration was $1.25 \mu \mathrm{g} / \mathrm{ml}$. The fluorescence was much greater in the lower $\mathrm{pH}$ ranges (Fig. 2). The slopes of the class I and class III curves diverge at $\mathrm{pH} 6.0$, with the class III cells showing greater response in the presence of STC. 


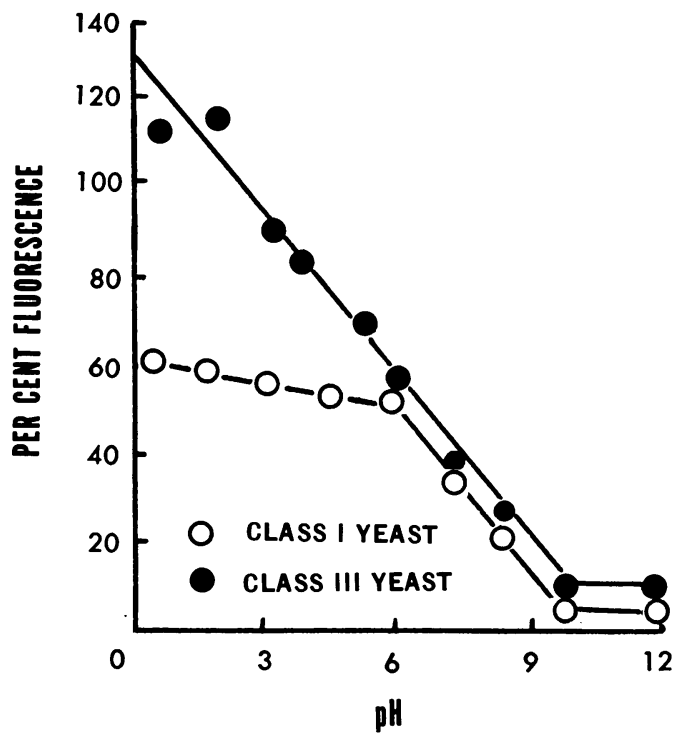

FIG. 2. Effect of $p H$ on fluorescence of STC adsorbed on class $I$ and class III yeast cells. Fluorescence of quinine standard was 100.

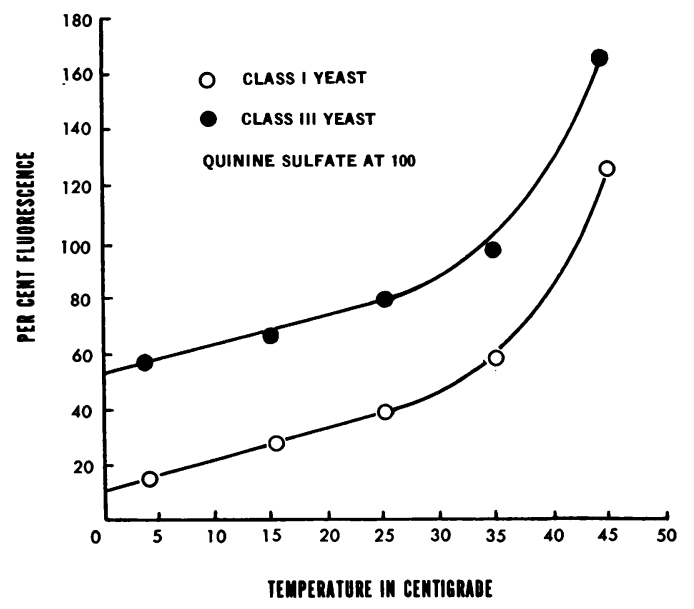

FIG. 3. Effect of temperature, during shaking process, on the adsorption of STC in the presence of cells, as represented by fuorescence.

The effect of temperature upon the adsorption of STC when the cells were shaken with the dye is given in Fig. 3. The amount of adsorption was measured by the degree of fluorescence by STC. There is a gradual increase in fluorescence as the temperature is increased, with a rapid rise for both strains at temperatures above $35 \mathrm{C}$.

If cells of the two classes of yeasts are mixed separately with STC in a concentration of 2.50
TABLE 1. Differences in fluorescence of class $I$ and class III yeast cells after treatment with STC, and the effect of storage at $4 C$ prior to treatment

\begin{tabular}{|c|c|c|c|c|c|}
\hline \multirow{3}{*}{ Storage time } & \multicolumn{4}{|c|}{ Fluorescence } & \multirow{3}{*}{$\begin{array}{c}\text { Final } \\
\text { OD of } \\
\text { cell sus- } \\
\text { pensions }\end{array}$} \\
\hline & \multicolumn{2}{|c|}{ Class I yeast } & \multicolumn{2}{|c|}{ Class III yeast } & \\
\hline & $\begin{array}{c}\text { No. of } \\
\text { samples }\end{array}$ & Avg & $\begin{array}{c}\text { No. of } \\
\text { samples }\end{array}$ & Avg & \\
\hline days & & & & & \\
\hline 0 & 12 & 58.5 & 12 & 97.6 & 1.3 \\
\hline 2 & 12 & 55.2 & 12 & 109.5 & 1.3 \\
\hline 8 & 6 & 55 & 6 & 98 & 1.3 \\
\hline Cells only & 6 & 0 & 6 & 0 & 1.3 \\
\hline Quinine standard & 6 & 100 & 6 & 100 & 0 \\
\hline
\end{tabular}

TABLE 2. Detection of adsorbed linoleic acid on class I yeast cells, using STC method

\begin{tabular}{|c|c|c|}
\hline Variables & Adsorption & $\begin{array}{l}\text { OD in spectro- } \\
\text { photometer due } \\
\text { to yeast cells }\end{array}$ \\
\hline & $\%$ & \\
\hline Cells only ..... & 0 & 1.15 \\
\hline Cells plus lipid ..... & 0 & 1.15 \\
\hline Cells plus STC . . . . . . . & 29 & 1.15 \\
\hline $\begin{array}{l}\text { Cells coated with lipid } \\
\text { plus STC } \ldots \ldots \ldots \ldots\end{array}$ & 72 & 1.15 \\
\hline Lipid only. . . . . . . . . . & 0 & 0 \\
\hline Quinine sulfate standard. & 100 & 0 \\
\hline
\end{tabular}

$\mu \mathrm{g} / \mathrm{ml}$ in $0.001 \mathrm{M}$ phthalate buffer $(\mathrm{pH} 3.8)$ at 26 $\mathrm{C}$, the difference in the degree of fluorescence between the classes is as represented in Table 1 . Under these conditions, class III cells are much more fluorescent than are the class I cells.

In preliminary experiments, it was observed that linoleic acid, when mixed with STC, exhibited a very strong fluorescence. Kleinzeller (1948) showed that linoleic acid is present in the cells of Saccharomyces cervisiae, and Reichert (1945) demonstrated the presence of the lipid in Candida (Torulopsis) utilis. Therefore, class I nonflocculent cells were coated with linoleic acid, and these cells were treated with STC (Table 2). For these experiments, $2.0 \mathrm{ml}$ of purified linoleic acid were added to $8 \mathrm{ml}$ of washed cells in $0.001 \mathrm{M}$ phthalate buffer. The tubes containing the mixture were shaken for $10 \mathrm{~min}$, and the contents were placed in separatory funnels. The cell suspension was drawn off and washed three times with $0.001 \mathrm{~m}$ buffer to remove any intercellular 


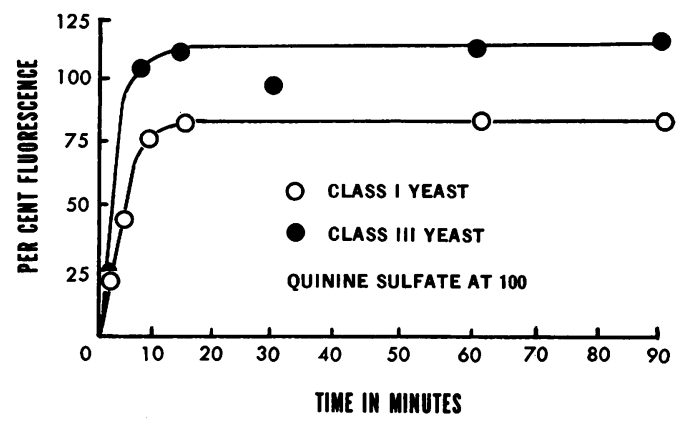

FIG. 4. Rate of adsorption of STC on yeast cells, as measured by fluorescence at $p H$ 3.8.

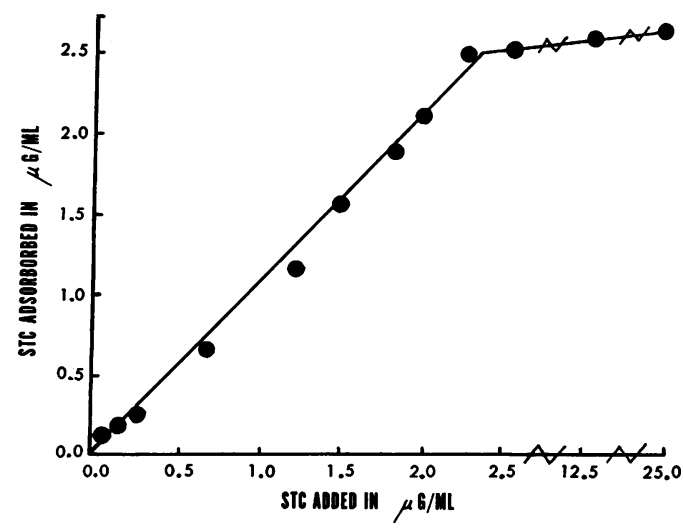

FIG. 5. Maximal adsorption of $S T C$, in relation to concentration, by class III yeast cells, $3.25 \mathrm{mg}$ $(d r y w t) / m l$.

lipid. Then the cells were shaken with STC for 10 min, and the fluorescence was determined after the cells were washed three times in $0.001 \mathrm{~m}$ buffer.

Substances other than lipids do not adsorb a measurable amount of STC and, therefore, do not fluoresce. Some of the substances tested were glucose, mannose, protein (bovine serum albumin), yeast nucleic acid, and yeast polysaccharide. The yeast polysaccharide was the extracellular water-soluble polysaccharide of Hansenula capsulata which was precipitated with ethanol and purified according to the method of Heidelberger et al. (1950). These tests were qualitative, and involved the addition of $1 \mathrm{ml}$ of STC in acetone to $5 \mathrm{mg}$ of the respective powders. After 10 min, the acetone solution of STC was decanted from the substrates and the degree of fluorescence was determined with a UV lamp that emitted light with a wavelength of $360 \mathrm{~m} \mu$.

Kinetics of STC adsorption by class III cells.
The rate of adsorption revealed by the fluorescence was quite rapid, attaining a maximum within about 15 min (Fig. 4). There is a direct relationship between the amount of STC added and the amount adsorbed (Fig. 5), until the adsorption reaches a maximum of $2.5 \mu \mathrm{g} / \mathrm{ml}$ for 9 $\mathrm{ml}$ of cells with an optical density of 1.30 , which corresponds to a dry weight of $3.25 \mathrm{mg} / \mathrm{ml}$ of cells. This indicated saturation kinetics and suggested that when the "combining sites" are filled no more of the STC can be adsorbed.

When different cell concentrations were mixed with a constant level of STC, the amount of unadsorbed dye $(\mu \mathrm{g} / \mathrm{ml})$ was the equilibrium concentration of STC in relation to dry cell weight $(\mathrm{mg} / \mathrm{ml})$. For this experiment, $1 \mathrm{ml}$ of appropriate yeast-cell density was added to $9 \mathrm{ml}$ of STC $(1.25$ $\mu \mathrm{g} / \mathrm{ml}$ ) in buffer-glucose in $18-\mathrm{mm}$ tubes, so that the final concentration of cells in the different tubes varied from 0 to $4 \mathrm{mg}$ (dry wt) $/ \mathrm{ml}$. The tubes were mixed on the shaker for $10 \mathrm{~min}$ at 26 $\mathrm{C}$, and the amount of unadsorbed dye in each tube was assayed by fluorescence. Cells which

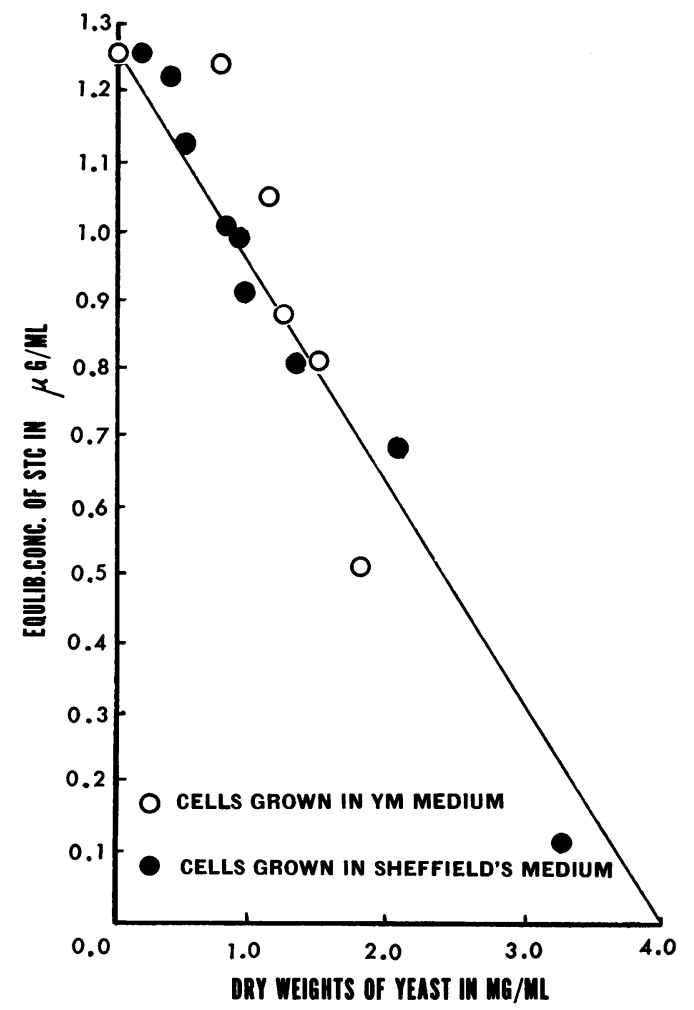

FIG. 6. Equilibrium concentration of dye for varying dry weights of class III cells. 
TABLE 3. Adsorption of STC on class III yeasts grown in YM broth and defined medium*

\begin{tabular}{ccccc}
\hline$C$ & $m$ & $x$ & $x / m$ & $\frac{C}{x / m}$ \\
\hline$\mu g / m l$ & $m g / m l$ & $\mu g / m l$ & $\mu g / m l$ & $m g / m l$
\end{tabular}

(a) $Y M$ broth

$\begin{array}{llllr}1.25 & 0.00 & 0.00 & - & - \\ 1.23 & 0.74 & 0.02 & 0.03 & 41.00 \\ 1.03 & 1.10 & 0.22 & 0.20 & 5.15 \\ 0.87 & 1.19 & 0.38 & 0.32 & 2.72 \\ 0.80 & 1.47 & 0.45 & 0.31 & 2.58 \\ 0.51 & 1.73 & 0.40 & 0.25 & 2.04 \\ 0.06 & 3.25 & 1.15 & 0.35 & 0.18\end{array}$

(b) Defined medium

$\begin{array}{llllr}1.25 & 0.00 & 0.00 & - & - \\ 1.22 & 0.44 & 0.03 & 0.07 & 17.40 \\ 1.11 & 0.53 & 0.14 & 0.26 & 2.34 \\ 1.06 & 0.60 & 0.19 & 0.32 & 3.32 \\ 1.00 & 0.79 & 0.25 & 0.32 & 3.12 \\ 0.98 & 0.83 & 0.27 & 0.33 & 2.97 \\ 0.90 & 0.97 & 0.35 & 0.36 & 2.50 \\ 0.80 & 1.25 & 0.45 & 0.36 & 2.22 \\ 0.69 & 2.01 & 0.56 & 0.28 & 2.46\end{array}$

* Cell weight was varied; STC was held constant at $1.25 \mu \mathrm{g} / \mathrm{ml}$. $C$ represents equilibrium concentration of STC left in the cell-free mixture after adsorption; $m$ represents the weight of yeast cells employed; $x$ represents the weight of STC adsorbed per unit volume (liquid); $x / m$ represents the weight of STC adsorbed per unit weight of cells; and $\frac{C}{x / m}$ represents the supernatant STC concentration divided by the weight of STC adsorbed per unit weight of cells.

had been cultivated in the defined salts medium exhibited less variation in the amount of residual dye than did cells grown in YM medium (Fig. 6 and Table 3).

The monomolecular adsorption law of Langmuir indicates that a straight line should result when the value $\frac{C}{x / m}$ is plotted against $C$. The quantity $C$ represents the amount of STC left in the supernatant fraction after adsorption by the cells; $m$ is the dry weight of cells in $\mathrm{mg} / \mathrm{ml} ; x$ is weight of STC adsorbed per $\mathrm{ml}$ of liquid volume; and $x / m$ is the weight of STC adsorbed in $\mu \mathrm{g}$ per mg (dry wt) of cells. That the adsorption of STC follows such a law is shown in Fig. 7 (data for this figure were obtained from Table 3 and Fig. 6).

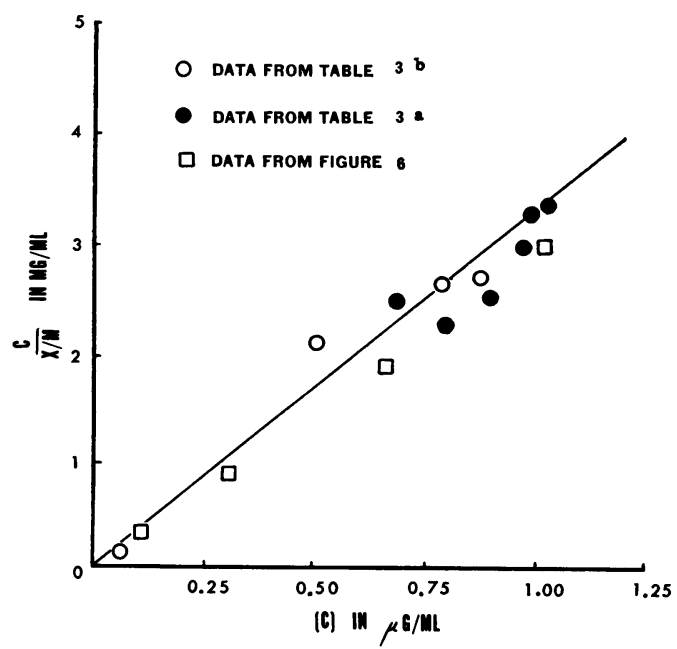

FIG. 7. Langmuir adsorption graph for adsorption of STC by class III cells.

Observation with fluorescence microscope of STC on cells. Mature cells that adsorbed STC exhibited a uniform surface fluorescence. Young cells and buds of cells had a more intense fluorescence, especially prominent at the neck of the bud. If STC was applied to cells whose walls had been ruptured by shaking with glass beads, there was, in addition, an internal fluorescence. This indicates that only damaged cell membranes are permeable to the STC molecule.

\section{Discussion}

The results reported in this study strongly suggest that class III flocculent yeasts have either more lipids on their cell-wall surface, or a different type of lipid which has a greater affinity for fatsoluble fluorescent dye. Other studies in our laboratory (Lycette and Hedrick, 1962), using uranyl nitrate ions, lecithinase, and certain lipid solvents as deflocculating agents, supply evidence which indicates that surface phospholipids may play some role in flocculation. The involvement of lipids in yeast flocculation is quite analogous to the role attributed to surface fats in different agglutination reactions associated with bacteria.

Sentheshanmuganathan and Nickerson (1962) recently demonstrated that cells of Trigonopsis variabilis, cultured in the presence of methionine, are mostly triangular in morphology and have more cell-wall phospholipids than do ellipsoidal cells grown in the absence of added methionine.

Our observations that young cells and the base 
of buds fluoresce to a greater degree than do the walls of older cells are in agreement with the report by Darken (1961) on her work with diaminostilbene fluorescent dye, which is more soluble in water than is STC. This may indicate that lipids or phospholipids, or both, are synthesized in the cell walls or membranes of dividing cells. Fluorescent dyes should provide a technique for fundamental studies of the sequences in the growth and division of cells. Nishi (1961) showed that the phospholipid concentration of Aspergillus niger spores is increased during their germination.

\section{LITERATURE CITED}

Bekken, J. H., and A. Tasman. 1942. Uber den Zusammenhaug zwischen der sauerfestigheit und dem Fluoreszenzvermogen der Tuberkelbazillus. Arch. Hyg. Bakteriol. 127:7.

Darken, M. A. 1961. Application of fluorescent brighteners in biological techniques. Science 133:1704.

Darken, M. A. 1962. Absorption and transport of fluorescent brighteners by microorganisms. Appl. Microbiol. 10:387-393.

Gortner, R. A. 1949. Outline of biochemistry, 3rd ed., p. 177. John Wiley \& Sons, Inc., New York.

Heidelberger, M., C. M. MacLeod, H. MarkowITZ, AND A. S. RoE. 1950. Improved methods for the preparation of the specific polysaccharides of pneumococcus. J. Exptl. Med. 91:341-349.

KLEINZeLler, A. 1948. Synthesis of lipids. Advan. Enzymol. 8:299-341.

LYCETTE, R. M., AND L. R. HEDRICK. 1961. Use of fat-soluble fluorescent brighteners on microorganisms. Science 134:1415.

LyCETTE, R. M., AND L. R. HedRick. 1962. Action of deflocculating agents on Saccharomyces cerevisiae class III brewers' yeast. Appl. Microbiol. 10:428-430.

Mankiewicz, C. 1952. The action of lipolytic enzymes of Galleria malonella on virulent Mycobacterium tuberculosis. Can. J. Biochem. Physiol. 30:106.

NisHI, A. 1961. Role of polyphosphate and phospholipid in germinating spores of Aspergillus niger. J. Bacteriol. 81:10-19.

REICHERT, R. R. 1945. Lipids of grain yeast (Torula utilis). I. Composition of acetone, soluble lipids. Helv. Chim. Acta 28:484-495.

Sentheshanmuganathan, S., and W. J. Nickerson. 1962. Composition of cells and cell walls of triangular and ellipsoidal forms of Trigonopsis variabilis. J. Gen. Microbiol. 27:451-464.

Wickerham, L. J. 1946. A critical evaluation of the nitrogen assimilation tests commonly used in the classification of yeasts. J. Bacteriol. 52:292-301. 